$\mathrm{Nr} 6$

WARSZAWA-

KRAKÓw 2003

TADEUSZ STRYJAKIEWICZ, JACEK WAJDA

Uniwersytet Adama Mickiewicza Poznań

\title{
Organizacja przestrzenna grup kapitałowych jako problem badawczy geografii ekonomicznej
}

Ziemia, praca i kapitał - to trzy główne czynniki produkcji wyróżniane przez klasyczną ekonomię. O ile ziemia wraz z jej bogactwami i użytkami, a także czynnik pracy (ludzie

z ich kwalifikacjami i umiejętnościami) stanowią przedmiot zainteresowania nie tylko ekonomii, ale i geografii od początku jej istnienia, to kapitał - jego przepływy i przestrzenną alokację należy uznać za zaniedbany problem badawczy w geografii ekonomicznej. Wpływa na to szereg przyczyn, ale najważniejszymi są zapewne: trudno uchwytny (a przy zastosowaniu obecnych technik komunikacyjnych wręcz „niewidzialny”, niematerializujący się) charakter obrotu kapitału oraz poufność danych.

Proces globalizacji stawia jednak przed geografią ekonomiczną nowe wyzwania. Wynikają one m.in. z wielkości globalnej cyrkulacji kapitału oraz nowych form jego alokacji. Podczas gdy roczny wolumen światowego handlu zagranicznego wynosi ok. 6 bilionów USD, to obroty kapitałowe w skali globalnej szacuje się na ok. 1,5 biliona USD dziennie (McKinsey Quarterly, 4/2000). Coraz większego znaczenia nabierają przy tym różne formy koncentracji kapitału, zarówno organizacyjnej, jak i przestrzennej. Jedną z takich form są grupy kapitałowe.

Pojęciu grupy kapitałowej poświęcono bogatą literaturę ekonomiczno-prawną (np. Haus 1993; Sołtysiński 1994; Jagoda, Haus 1995; Sokołowicz 1998; Nogalski 2000); stąd jego szersze omówienie nie jest celem niniejszego artykułu. W naszej analizie przyjmujemy za S. Sołtysińskim (1994, s. 223) następującą definicję: grupa kapitałowa (zgrupowanie spółek) oznacza hierarchiczną strukturę organizacyjną złożoną z dwóch lub większej liczby spółek podległych scentralizowanemu zarządzaniu, w której zazwyczaj tylko jeden członek grupy (podmiot dominujący) zajmuje pozycję w pełni niezależną ekonomicznie i sprawuje kontrolę we wszystkich lub kluczowych dziedzinach działalności grupy. Model struktury grupy kapitałowej przedstawia ryc. 1.

Przedmiotem zainteresowania geografów ekonomicznych jest w szczególności organizacja przestrzenna grup kapitałowych. Termin „organizacja” według R. Domańskiego (1982, s. 262) określa „sposób, według którego elementy jakiegoś zbioru są porządkowane w całość i wyznaczane do pełnienia określonych funkcji”. W odniesieniu do organizacji przestrzennej szczególnie istotne są lokalizacje tych elementów oraz relacje przestrzenne między nimi (np. skupienie-rozproszenie). Należy przy tym zwrócić uwagę, że mówiąc o analizie organizacji przestrzennej grup kapitałowych mamy na myśli nie tylko lokalizacje i powiązania między poszczególnymi elementami łańcucha produkcji (zaopatrzenie- 
produkcja-dystrybucja), ale przede wszystkim przestrzenną strukturę zaangażowania kapitałowego właścicieli (ich udziałów w grupie) oraz form zależności kapitałowej (typy spółek $\mathrm{i}$ ich hierarchia w wymiarze przestrzennym).

rys 1 


\section{GRUPY KAPITAŁOWE W POLSCE}

Grupy kapitałowe jako nowa forma organizacji działalności gospodarczej zaczęły wyłaniać się w Polsce od 1990 r., wraz z postępującym procesem transformacji systemowej i otwarciem gospodarki na procesy globalne. Niektóre z nich powstały na bazie dawnych przedsiębiorstw z okresu gospodarki nakazowo-rozdzielczej (kombinatów przemysłowych, central handlu zagranicznego), inne są efektem ekspansji i konsolidacji rodzimego kapitału prywatnego (przejmującego również prywatyzowane firmy państwowe).

Obecnie najsilniejsze polskie grupy kapitałowe mają rodowód w przedsiębiorstwach socjalistycznych. Chodzi szczególnie o te przedsiębiorstwa, które zdołały w gospodarce planowej zbudować duży potencjał gospodarczy, a po 1989 r. okazały się zdolne, niejednokrotnie dzięki swej monopolistycznej pozycji i powiązaniom z ośrodkami władzy, do przestawienia się na tory gospodarki rynkowej.

Najczęstszym sposobem rozszerzania działalności przez polskie grupy kapitałowe jest częściowy lub całkowity wykup innych przedsiębiorstw, a nie budowanie własnych nowych oddziałów. Jest to związane z dużą ofertą prywatyzowanych przedsiębiorstw i atrakcyjnością takich operacji. Rzadko przedsiębiorstwo dominujące dywersyfikuje się poprzez rozwój wewnętrzny, czyli budowę przedsiębiorstw w nowych sektorach od podstaw. Jeśli jednak takie inwestycje się pojawiają, to dotyczą najczęściej branż kluczowych dla grup kapitałowych lub zupełnie nowych dziedzin działalności.

Tabela 1. Etapy procesu globalizacji polskiego przemysłu i ich charakterystyka

\begin{tabular}{|c|c|c|}
\hline Etap & Formy & $\begin{array}{l}\text { Cele makroekonomiczne } \\
\text { polskiej gospodarki }\end{array}$ \\
\hline $\begin{array}{l}\text { I } \\
\text { (okres gospo- } \\
\text { darki naka- } \\
\text { zowo-roz- } \\
\text { dzielczej) }\end{array}$ & $\begin{array}{l}\text { nieliczne próby tworzenia joint ventures } \\
\text { z przedsiębiorstwami państwowymi } \\
\text { byłego bloku wschodniego (np. spółka } \\
\text { „Haldex”) } \\
\text { od } 1977 \text { r. lokalizacja małych przedsię- } \\
\text { biorstw z kapitałem zagranicznym, tzw. } \\
\text { firm polonijnych (np. „Inter- } \\
\text { Fragrances”) }\end{array}$ & $\begin{array}{l}\text { realizacja bieżących zadań planu } \\
\text { gospodarczego, takich jak: poprawa } \\
\text { bilansu płatniczego, substytucja } \\
\text { importu itp. }\end{array}$ \\
\hline $\begin{array}{l}\text { II } \\
\text { (okres trans- } \\
\text { formacji) }\end{array}$ & $\begin{array}{l}\text { udział przedsiębiorstw wielonarodowych } \\
\text { w prywatyzacji polskich przedsiębiorstw } \\
\text { państwowych } \\
\text { bezpośrednie inwestycje „od podstaw” } \\
\text { (greenfield investments) } \\
\text { inwestycje portfelowe (portfolio invest- } \\
\text { ments) } \\
\text { system zleceń i podwykonawstwa w } \\
\text { ramach tzw. przerobu uszlachetniającego }\end{array}$ & $\begin{array}{l}\text { „zastrzyk” kapitałowy dla gospodarki } \\
\text { wzbogacenie asortymentu produkcji na } \\
\text { rynku krajowym } \\
\text { ułatwienie dostępu do nowych rynków } \\
\text { za granicą } \\
\text { zmiany zarządzania i technologii } \\
\text { w prywatyzowanych firmach } \\
\text { zachowanie i tworzenie miejsc pracy } \\
\text { włączanie polskich podmiotów gospo- } \\
\text { darczych w globalne sieci przemysło- } \\
\text { we }\end{array}$ \\
\hline $\begin{array}{l}\text { III } \\
\text { (okres przy- } \\
\text { szłej, w pełni } \\
\text { ukształtowa- } \\
\text { nej gospodar- } \\
\text { ki rynkowej) }\end{array}$ & $\begin{array}{l}\text { wyłonienie się silniejszych polskich grup } \\
\text { kapitałowych i swobodny przepływ kapi- } \\
\text { tału w obie strony }\end{array}$ & $\begin{array}{l}\text { pełne wykorzystanie przewagi konku- } \\
\text { rencyjnej kraju } \\
\text { zdolność do kreowania innowacji } \\
\text { uniknięcie pozycji „kraju surowcowego” }\end{array}$ \\
\hline
\end{tabular}


Źródło: Stryjakiewicz 1999, s. 137.

T. Stryjakiewicz (1999) charakteryzując etapy globalizacji polskiej gospodarki (tab. 1) stwierdził, że wyłonienie się silnych grup kapitałowych jest warunkiem jej skutecznego konkurowania na arenie globalnej. Stąd celem dalszej części artykułu jest pokazanie na wybranych przykładach, jak przebiega proces kształtowania się polskich grup kapitałowych i ja-kie są najważniejsze cechy ich organizacji przestrzennej. Obiektami analizy są dwie grupy kapitałowe o odmiennej genezie, skali i profilu działalności:

a) KGHM Polska Miedź S.A. - przykład grupy kapitałowej w przemyśle surowcowym, wywodzącej się ze struktury ukształtowanej w gospodarce nakazowo - rozdzielczej;

b) OPTIMUS S.A. - przykład grupy kapitałowej powstałej „od podstaw” w okresie transformacji, opartej na kapitale prywatnym, reprezentującej przemysł i usługi zaawansowanej technologii.

Przedmiotem analizy są:

- rozkład przestrzenny siedzib spółek badanych grup kapitałowych,

- zaangażowanie kapitałowe spółek dominujących w inne spółki według branż,

- rozkład i wielkość akcjonariatu badanych spółek.

\section{KSZTAŁTOWANIE SIĘ I ORGANIZACJA PRZESTRZENNA WYBRANYCH GRUP KAPITAŁOWYCH}

\section{KGHM Polska Miedź S.A.}

Początki kształtowania się Grupy Kapitałowej KGHM Polska Miedź S.A. sięgaja okresu, w którym w Kombinacie Górniczo-Hutniczym Miedzi w Lubinie - Przedsiębiorstwie Państwowym rozpoczął się proces przekształceń strukturalnych i własnościowych, zainicjowany w połowie 1990 r. W 1991 r. decyzją ministra przekształceń własnościowych wykreślono Kombinat Górniczo-Hutniczy Miedzi z rejestru przedsiębiorstw państwowych, przekształcając go jednocześnie w spółkę prawa handlowego - jednoosobową spółkę skarbu państwa. Nowo powstały podmiot KGHM Polska Miedź S.A. przejął wszystkie prawa i obowiązki dotychczasowego przedsiębiorstwa państwowego.

Grupa Kapitałowa KGHM Polska Miedź składa się z 32 elementów (tab. 2):

- podmiotu dominującego KGHM Polska Miedź S.A.,

- 28 podmiotów zależnych (w tym 14 bezpośrednio i 14 pośrednio),

- 3 podmiotów stowarzyszonych.

Strukturę organizacyjną Grupy Kapitałowej KGHM Polska Miedź S.A. przedstawia rycina 2.

KGHM Polska Miedź S.A. z siedzibą w Lubinie zatrudnia (2000 r.) 18562 pracowników i jest jednym z największych polskich eksporterów (3 226 200,95 tys. zł w 2000 r.).

KGHM Polska Miedź S.A., jako podmiot dominujący Grupy Kapitałowej, jest największym producentem miedzi w Europie z własnych zasobów górniczych, piątym co do wielkości producentem miedzi na świecie oraz największym światowym producentem sre- 
bra. Spółka produkuje miedź, srebro oraz, w mniejszych ilościach, złoto i inne metale, w trzech zakładach górniczych, trzech hutach, walcowni miedzi oraz na wydziale metali szlachetnych.

Tabela 2. Grupa Kapitałowa KGHM Polska Miedź S.A.

\begin{tabular}{|c|c|c|c|}
\hline Lp. & Nazwa podmiotu & $\begin{array}{c}\text { Siedziba } \\
\text { podmiotu }\end{array}$ & $\begin{array}{c}\text { Udział KGHM Polska } \\
\text { Miedź S.A. w kapitale } \\
\text { podstawowym spółki } \\
\text { w } \%\end{array}$ \\
\hline 1 & KGHM Polska Miedź S.A. & Lubin & - \\
\hline 2 & CBPM CUPRUM Sp. z o.o. & Wrocław & 100,00 \\
\hline 3 & DFM Zanam Sp. z o.o. & Polkowice & 100,00 \\
\hline 4 & DKE Oława Sp. z o.o. & Oława & 100,00 \\
\hline 5 & DSI S.A. & Lubin & 100,00 \\
\hline 6 & Energetyka Sp. z o.o. & Lubin & 100,00 \\
\hline 7 & FIK KGHM Metale S.A. & Lubin & 100,00 \\
\hline 8 & INERFERIE Sp. z o.o. & Lubin & 100,00 \\
\hline 9 & KGHM Kupferhandel GmbH & Wiedeń & 100,00 \\
\hline 10 & KGHM Polish Copper Ltd. & Londyn & 100,00 \\
\hline 11 & Lefana Sp. z o.o. & Legnica & 100,00 \\
\hline 12 & Miedziowe Centrum Zdrowia S.A. & Lubin & 100,00 \\
\hline 13 & POL-MIEDŹ TRANS Sp. z o.o. & Lubin & 100,00 \\
\hline 14 & PeBeKa S.A. & Lubin & 100,00 \\
\hline 15 & Telefonia Lokalna S.A. & Wrocław & 100,00 \\
\hline 16 & Zakład Doświadczalny Sp. z o.o. & Lubin & 100,00 \\
\hline 17 & ZUW Sp. z o.o. & Lubin & 100,00 \\
\hline 18 & ZWG Sp. z o.o. & Iwiny & 100,00 \\
\hline 19 & Zakłady Mechaniczne Legmet Sp. z o.o. & Legnica & 100,00 \\
\hline 20 & Centrum Badania jakości Sp. z o.o. & Lubin & 99,99 \\
\hline 21 & K.G.H.M. CONGO s.p.r.l. & Lubumbashi & 99,98 \\
\hline 22 & TUW CUPRUM & Lubin & 93,14 \\
\hline 23 & KGHM METRACO Sp. z o.o. & Legnica & 91,58 \\
\hline 24 & AQUAKONRAD S.A. & Iwiny & 90,40 \\
\hline 25 & HEFRA S.A. & Warszawa & 90,24 \\
\hline 26 & KWARCE S.A. & Mikołajewice & 80,69 \\
\hline 27 & NATUROPAK Sp. z o.o. & Wilków & 80,69 \\
\hline 28 & Polskie Centrum Promocji Miedzi S.A. & Wrocław & 65,00 \\
\hline 29 & WMN Sp. z o.o. & Gliwice & 64,04 \\
\hline 30 & PHP MERCUS Sp. z o.o. & Polkowice & 46,27 \\
\hline 31 & Walcownia Metali ŁABĘDY S.A. & Gliwice & 34,11 \\
\hline 32 & FORSOC KSANTE Sp. z o.o. & Polkowice & 30,00 \\
\hline
\end{tabular}


Źródło: Opracowanie własne na podstawie www.kghm.pl, 10.12.2001 r.

Ryc. 2 
Działalność pozostałych spółek wchodzących w skład Grupy Kapitałowej, nastawiona jest głównie na:

- świadczenie usług na rzecz KGHM Polska Miedź S.A. (np. usług socjalno-bytowych),

- zaopatrywanie KGHM Polska Miedź S.A. w materiały i urządzenia do produkcji,

- sprzedaż produktów KGHM Polska Miedź S.A. odbiorcom krajowym i zagranicznym.

Rozkład przestrzenny krajowych spółek Grupy Kapitałowej przedstawia ryc. 3, a rozkład spółek zagranicznych - ryc. 4.

Analizując lokalizację spółek krajowych można stwierdzić dużą aktywność inwestycyjną KGHM Polska Miedź S.A. w lokalnym otoczeniu. W samym tylko Lubinie siedzibę ma 11 spółek Grupy Kapitałowej, natomiast w promieniu ok. 60 km od Lubina - 24 spółki (czyli 75\% spółek Grupy Kapitałowej znajduje się w bezpośrednim, lokalnym otoczeniu KGHM Polska Miedź S.A.).

W przypadku spółek zagranicznych, dwie z nich (KGHM Polish Copper Ltd. i KGHM Kupferhandel G.m.b.H.) stanowią zagraniczne oddziały handlowe KGHM Polska Miedź S.A. Obszar działalności KGHM Polish Copper Ltd. z siedzibą w Londynie obejmuje w większości państwa zachodnioeuropejskie, natomiast KGHM Kupferhandel G.m.b.H. z siedzibą w Wiedniu obsługuje państwa południowej i środkowo-wschodniej Europy.

Spółka K.G.H.M. CONGO s.p.r.l. stanowi zagraniczny oddział górniczy, eksploatujący - na podstawie umowy z dnia 7 stycznia 1997 r. - miedź i kobalt do głębokości $30 \mathrm{~m}$ ze złoża Kimpe położonego w Demokratycznej Republice Konga. Ocena efektywności tego przedsięwzięcia budzi szereg wątpliwości (nie jest to jednak przedmiotem naszego artykułu).

Zaangażowanie KGHM Polska Miedź S.A. w spółki dotyczy różnych branż. Można je podzielić na trzy grupy:

1. Spółki bezpośrednio branżowo powiązane z dzialalnością spółki dominującej. Ich lokalizacje przedstawia ryc. 5 .

Spółki świadczyły usługi na rzecz KGHM Polska Miedź S.A. w następujących dziedzinach:

- usługi wydobywcze: FIK KGHM Metale S.A., KWARCE S.A., K.G.H.M. CONGO s.p.r.l.,

- usługi budowlane i wiertnicze: PeBeKa S.A.,

- usługi transportowe: POL-MIEDŹ TRANS Sp. z o.o., KGHM METRACO Sp. z o.o.,

- handel produktami i towarami: POL-MIEDŹ TRANS Sp. z o.o., KGHM Polish Copper Ltd., KGHM Kupferhandel G.m.b.H., WM Łabędy S.A., PHP MERCUS Sp. z o.o., KGHM METRACO Sp. z o.o.,

- usługi finansowe, prawnicze, doradztwo i zarządzanie kontrolowanymi podmiotami: FIK KGHM Metale S.A., DSI S.A.,

- produkcja metali: FIK KGHM Metale S.A., WM Łabędy S.A., KGHM METRACO Sp. z o.o.,

- produkcja wyrobów elektromechanicznych: PHP MERCUS Sp. z o.o.,

- działalność marketingowa: Polskie Centrum Promocji Miedzi S.A., DSI S.A.

$6)$.

2. Spółki częściowo branżowo powiązane z działalnością spółki dominującej (ryc. 
Firmy te prowadziły działalność w następujących dziedzinach:

- działalność produkcyjna: HEFRA S.A., Lefana Sp. z o.o., Miedziowe Centrum Zdrowia S.A., FORSOC KSANTE S.A., DFM Zanam Sp. z o.o., Zakład Doświadczalny Sp. z o.o., ZWG Sp. z o.o., ZUW Sp. z o.o., ZM Legmet Sp. z o.o.,

Ryc. 3. Rozkład przestrzenny krajowych spółek Grupy Kapitałowej KGHM Polska Miedź S.A. 
Ryc. 4. Rozkład przestrzenny zagranicznych spółek Grupy Kapitałowej KGHM Polska Miedź S.A. Źródło: Opracowanie własne 
Ryc. 5. Rozkład przestrzenny spółek bezpośrednio branżowo powiązanych z działalnością KGHM Polska Miedź S.A.

Źródło: Opracowanie własne 
Ryc. 6. Rozkład przestrzenny spółek częściowo branżowo powiązanych z działalnością KGHM Polska Miedź S.A.

Źródło: Opracowanie własne 
Ryc. 7. Rozkład przestrzenny spółek nie związanych branżowo z działalnością KGHM Polska Miedź S.A.

Źródło: Opracowanie własne 
- działalność handlowa: HEFRA S.A., Lefana Sp. z o.o., FORSOC KSANTE S.A.,

- usługi remontowe i budowlane: DFM Zanam Sp. z o.o., ZM Legmet Sp. z o.o.,

- badania, doradztwo i analizy techniczne: CBPM CUPRUM Sp. z o.o., Centrum Badania Jakości Sp. z o.o.,

- usługi medyczne: Miedziowe Centrum Zdrowia S.A.,

- unieszkodliwianie i recycling odpadów: DKE Oława Sp. z o.o.

3. Spółki nie związane branżowo z dzialalnością spólki dominującej (ryc. 7).

Prowadziły one działalność w następujących dziedzinach:

- działalność radiowa i telewizyjna: Telewizja Familijna S.A.,

- usługi telekomunikacyjne: Polkomtel S.A., Telefonia Lokalna S.A.,

- działalność reasekuracyjna: PTR S.A.,

- usługi finansowe i ubezpieczeniowe: CUPRUM Bank S.A., TUW CUPRUM,

- działalność produkcyjna i handlowa: NATUROPAK Sp. z o.o., AQUAKONRAD

S.A., Energetyka Sp. z o.o.,

- usługi turystyczne i hotelarskie: INTERFERIE Sp. z o.o.

KGHM Polska Miedź S.A. jest spółką publiczną na podstawie decyzji Komisji Papierów Wartościowych w Warszawie z dnia 5 czerwca 1997 r. Kapitał akcyjny Spółki na dzień

12 października 2000 r. wynosił 2000000000 PLN i dzielił się na 200000000 akcji zwykłych na okaziciela o wartości nominalnej 10 PLN każda. W publicznej ofercie sprzedano 65732200 akcji, z czego:

- w ramach transzy krajowej 30000000 akcji,

- w ramach transzy zagranicznej 35732200 akcji.

Akcje KGHM Polska Miedź S.A. notowane są na Warszawskiej Giełdzie Papierów Wartościowych od 10 lipca 1997 r. Równocześnie z debiutem na GPW w Warszawie rozpoczął się obrót kwitami depozytowymi emitowanymi w oparciu o akcje KGHM Polska Miedź S.A. na Londyńskiej Giełdzie Papierów Wartościowych. Bankiem depozytowym dla programu kwitów depozytowych Spółki, począwszy od grudnia 2000 r., jest Bankers Trust (Grupa Deutsche Bank). Wcześniej funkcję tę pełnił Citibank N.A.

7 lipca 1999 r. do obrotu giełdowego wprowadzono 29995760 akcji pracowniczych, a począwszy od dnia 7 lipca 2000 r. udostępniono akcje będące w posiadaniu członków zarządu. Od tego momentu wszystkie akcje wyemitowane przez Spółkę wprowadzone są do obrotu giełdowego.

Strukturę akcjonariatu Spółki na dzień 12 października 2001 r. przedstawia ryc. 8. 


\section{OPTIMUS S.A.}

Żródło: Opracowanie własne na podstawie www.kghm.pl

OPTIMUS Sp. z o.o. została utworzona w 1988 roku przez Romana Kluskę w Nowym Sączu. Jej celem była produkcja i sprzedaż sprzętu komputerowego. Już w 1993 roku Spółka została największą firmą komputerową w Polsce. W 1994 roku stała się strategicznym partnerem dla Microsoft i Intel oraz jako pierwsza spółka sektora informatycznego zadebiutowała na Giełdzie Papierów Wartościowych w Warszawie. W 1996 roku, jako pierwsza firma w Europie Środkowo-Wschodniej, przeprowadziła emisję obligacji zamiennych na akcje.

Grupa Kapitałowa OPTIMUS S.A. powstała w wyniku inwestycji kapitałowych spółki OPTIMUS S.A. w inne spółki prawa handlowego oraz w drodze tzw. pączkowania, czyli wydzielania ze struktury spółki matki innych spółek, zajmujących się działalnościami pochodnymi lub nie związanymi z podstawową działalnością jej struktur. W $2001 \mathrm{r}$. nastąpiły istotne zmiany w strukturze własnościowej grupy (pojawienie się inwestora strategicznego). Przeprowadzona poniżej analiza organizacji przestrzennej OPTIMUSA dotyczy stanu z początku $2000 \mathrm{r}$.

Tabela 3. Grupa OPTIMUS S.A.

\begin{tabular}{|c|l|l|c|}
\hline Lp. & \multicolumn{1}{|c|}{ Nazwa podmiotu } & $\begin{array}{c}\text { Siedziba } \\
\text { podmiotu }\end{array}$ & $\begin{array}{c}\text { Udział } \\
\text { OPTIMUS S.A. } \\
\text { w kapitale pod- } \\
\text { stawowym spółki } \\
\text { w } \%\end{array}$ \\
\hline 1 & OPTIMUS S.A. & Nowy Sacz & - \\
\hline 2 & OPTIMUS IC S.A. & Nowy Sacz & 100 \\
\hline 3 & Optimus Direct Marketing & Nowy Sącz & 100 \\
\hline 4 & Optimus Dystrybucja S.A. & Nowy Sacz & 100 \\
\hline 5 & Optimus Holding S.A. & Bydgoszcz & 100 \\
\hline 6 & Optimus Real Estate S.A. & Warszawa & 100 \\
\hline 7 & Print Media Sp. z o.o. & Kraków & 100 \\
\hline 8 & OPTIMUS PASCAL S.A. & Bielsko-Biała & 75 \\
\hline 9 & OPTIMUS ITECH Sp. z o.o. & Kielce & 52 \\
\hline 10 & OPTIMUS BIS Sp. z o.o. & Częstochowa & 51 \\
\hline 11 & OPTIMUS COMFORT Sp. z o.o. & Rzeszów & 51 \\
\hline 12 & Printmark S.A. & Paryż & 50 \\
\hline
\end{tabular}

Źródło: Opracowanie własne na podstawie Prospektu emisyjnego OPTIMUS S.A., s. 215.

Grupa Kapitałowa OPTIMUS S.A. składa się z 12 elementów (tab. 3):

- podmiotu dominującego OPTIMUS S.A. z siedzibą w Nowym Sączu (599 zatrudnionych w 2000 r.),

- 10 jednostek zależnych (w tym 8 bezpośrednio i 2 pośrednio),

- 1 jednostki stowarzyszonej.

Strukturę organizacyjną Grupy Kapitałowej OPTIMUS S.A. przedstawia ryc. 9.

W ramach Grupy Kapitałowej prowadzona jest wspólna polityka gospodarowania, w związku z czym przedmiot działalności Grupy Kapitałowej OPTIMUS S.A. jest zgodny z przedmiotem działalności spółki dominującej - OPTIMUS S.A. i obejmuje:

- produkcję i dystrybucję sprzętu komputerowego,

- usługi z zakresu integracji systemowej i aplikacyjnej, 
- usługi i produkty internetowe,

- budowę i zarządzanie nieruchomościami.

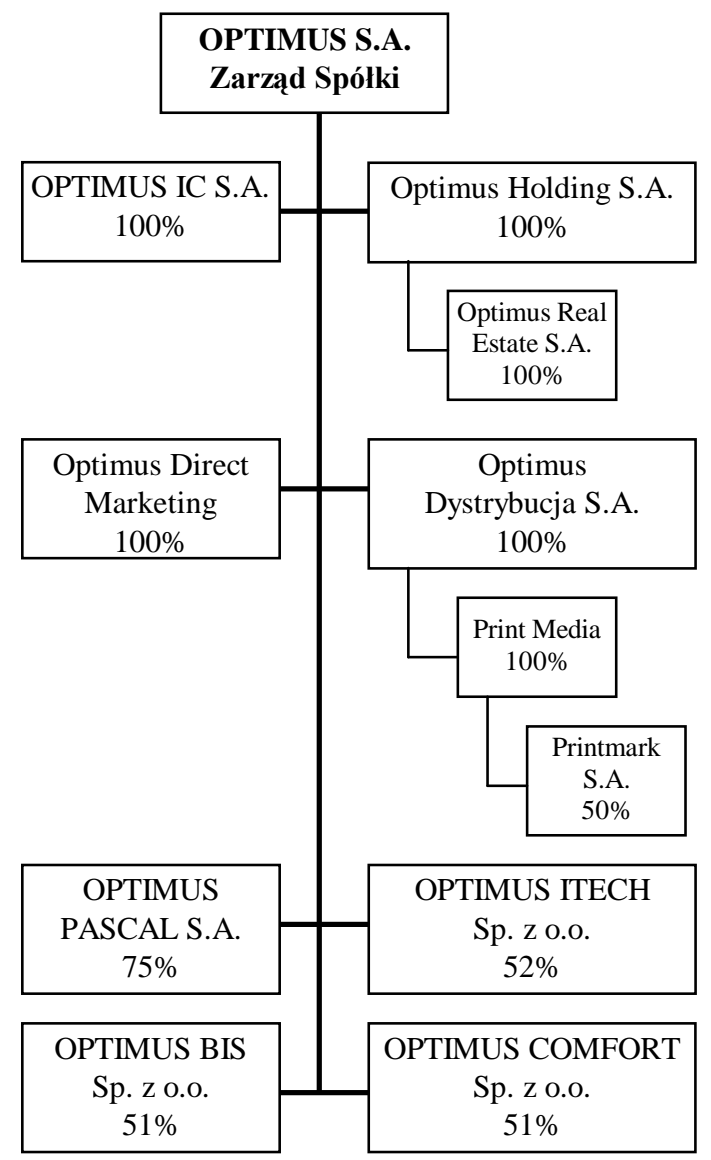

Ryc. 9. Struktura organizacyjna Grupy Kapitałowej OPTIMUS S.A.

Źródło: Opracowanie własne

Rozkład przestrzenny siedzib spółek Grupy Kapitałowej OPTIMUS S.A. przedstawia ryc. 10. Spółki wchodzące w skład Grupy są w większości firmami polskimi, skoncentrowanymi głównie w Polsce południowej. Jedyną firmą zlokalizowaną poza granicami kraju jest Printmark S.A., spółka stowarzyszona z OPTIMUS S.A., z siedzibą w Paryżu. W samym Nowym Sączu swoje siedziby miały 4 spółki Grupy Kapitałowej, natomiast większość siedzib pozostałych spółek zlokalizowana była w dużych miastach w promieniu do ok. 150 km od Nowego Sącza (Rzeszów, Kielce, Bielsko-Biała, Kraków), poza Tarnowem i miastami Górnego Śląska. 
Ryc. 10. Rozkład przestrzenny spółek Grupy Kapitałowej OPTIMUS S.A.

Źródło: Opracowanie własne 
Ryc. 11. Rozkład przestrzenny spółek bezpośrednio branżowo powiązanych z działalnością OPTIMUS S.A.

Źródło: Opracowanie własne 
Ryc. 12. Rozkład przestrzenny spółek nie związanych branżowo z działalnościa OPTIMUS S.A.

Źródło: Opracowanie własne 
Podobnie jak w przypadku KGHM Polska Miedź S.A. zaangażowanie OPTIMUS S.A. jako spółki dominującej Grupy Kapitałowej w inne spółki dotyczy różnych branż. Można je podzielić na 2 grupy:

1. Spółki bezpośrednio branżowo powiązane $z$ działalnością OPTIMUS S.A. Ich lokalizacje przedstawia ryc. 11 .

Podmioty te to firmy produkcyjne, handlowe i usługowe, zajmujące się zarówno sprzedażą i produkcją własnych wyrobów i usług, jak i sprzedażą produktów i usług OPTIMUS S.A.

2. Spółki nie związane branżowo z działalnością OPTIMUS S.A. (ryc. 12).

Firmy te prowadziły działalność w następujących branżach:

- wynajem, budowa i zarządzanie nieruchomościami: OPTIMUS Real Estate S.A.,

- usługi telekomunikacyjne: PAGI S.A.,

- usługi wydawnicze: OPTIMUS PASCAL S.A.,

- usługi finansowe: Optimus Leasing,

- działalność handlowa i usługowa: Print Media Sp. z o.o., Printmark S.A.

OPTIMUS S.A. jest spółką publiczną na podstawie decyzji Komisji Papierów Wartościowych w Warszawie z 1994 r. Kapitał akcyjny Spółki na dzień 31 grudnia 2000 roku wynosił 6884108 akcji o wartości nominalnej 1,00 PLN, w tym:

-1756 190 imiennych uprzywilejowanych (5 głosów na Walnym Zgromadzeniu Akcjonariuszy, pierwszeństwo w podziale majątku, umarzaniu i poborze),

- 80000 imiennych zwykłych,

- 5047918 zwykłych na okaziciela.

Od dnia 25 lipca 2001 r. do obrotu giełdowego wprowadzono 4727918 akcji.

Rok 2001 był bardzo ważny dla Spółki - do tej pory firma rodzinna, po 12 latach działalności, pozyskała inwestora - BRE Bank S.A. W 2. poł. 2001 r. BRE Bank S.A. podpisał list intencyjny $\mathrm{z}$ holdingiem medialnym ITI w sprawie sprzedaży części portalowej - Onet.pl.

Strukturę akcjonariatu Spółki na dzień 9 października 2001 r. przedstawia ryc. 13. Przestrzenna organizacja Grupy po tych zmianach jest aktualnie przedmiotem badań. 


\section{Źródło: Opracowanie własne na podstawie www.optimus.pl \\ PORÓWNANIE ORGANIZACJI PRZESTRZENNEJ \\ I STRATEGII ROZWOJU BADANYCH GRUP KAPITAŁOWYCH}

Porównanie organizacji przestrzennej badanych grup kapitałowych wskazuje na znaczące różnice $\mathrm{w}$ rozmieszczeniu spółek związanych $\mathrm{z}$ każdą z grup. Podczas gdy spółki KGHM Polska Miedź S.A. charakteryzują się tendencją koncentracji wokół siedziby spółki dominującej (z wyjątkiem spółek nie związanych bezpośrednio z głównym profilem działalności KGHM Polska Miedź S.A.), to spółki wchodzące w skład Grupy Kapitałowej OPTIMUS S.A. cechuje znaczne rozproszenie i słaba zależność lokalizacyjna od spółki dominującej (z wyjątkiem kilku spółek o największej zależności kapitałowej). Proces penetracji globalnych rynków przez obie grupy ma jak dotąd ograniczony zasięg. Tylko 3 firmy (KGHM Polish Copper Ltd., KGHM Kupferhandel G.m.b.H., K.G.H.M. CONGO s.p.r.l.) wchodzace w skład Grupy Kapitałowej KGHM Polska Miedź S.A. i 1 firma (Printmark S.A.) wchodząca w skład Grupy Kapitałowej OPTIMUS S.A. miały swoje siedziby za granicą.

Obie analizowane grupy różnią się również pod względem realizowanych przez nie strategii globalizacyjnych. Grupa Kapitałowa KGHM Polska Miedź S.A. skoncentrowała swą aktywność na nieudanej próbie rozwinięcia działalności wydobywczej w Demokratycznej Republice Konga. Natomiast naturalną drogą inwestowania nadwyżki finansowej przez OPTIMUS S.A. było poszerzenie branżowe i rynkowe zakresu działania m.in. na rynkach wschodnich i południowych sąsiadów Polski (Litwa, Ukraina, Słowacja). Inwestowano w dziedziny pokrewne technologicznie, rynkowo i organizacyjnie. Obok branży komputerowej, inwestowano w produkcję urządzeń fiskalnych, metkownic, branżę telekomunikacyjna, systemy transmisji danych, tworzenie oprogramowania oraz w działalność internetowa. Pozwalało to na umocnienie pozycji rynkowej, zdynamizowanie działalności podstawowej branży oraz zmniejszenie kosztów stałych.

Była to strategia racjonalna, pozwalająca wykorzystać mocne strony firmy i zmniejszyć ryzyko związane $\mathrm{z}$ inwestowaniem w nowe sektory. Pozycja dominująca w tym przypadku nie wyrażała się dużym udziałem w rynku, ale silną pozycją przetargową wobec dostawców

i odbiorców. Inwestowano również w spółki nie związane z podstawową działalnością OPTI-MUS S.A., w sektor nieruchomości, budowę autostrad, usługi wydawnicze i finansowe. Impulsem do takiego działania było pojawienie się korzystnych okazji rynkowych.

Równocześnie z realizacją strategii dywersyfikacji działalności OPTIMUS S.A. szukał możliwości rozwoju w rozszerzaniu przestrzennego obszaru działania. Grupa Kapitałowa rozwijała się poprzez inwestowanie w rozwój własnych filii i rozbudowę istniejącej bazy oraz poprzez zawieranie aliansów strategicznych w formie umów o współpracy (czego przykładem było zawarcie umów z firmą $\mathrm{SCO}$ w sprawie dostarczania unix-owych systemów operacyjnych oraz z firmą IFS Poland Sp. z o.o. w sprawie kompleksowych rozwiązań informatycznych klasy) i spółek kapitałowych (Optimus Lockheed Martin Information Technology Group S.A. - wspólne przedsięwzięcie OPTIMUS S.A. i Lockheed Martin Co. oraz PAGI S.A. - wspólne przedsięwzięcie OPTIMUS S.A. i PROKOM Software S.A.). 
Zaangażowanie inwestorów w akcje zarówno KGHM Polska Miedź S.A., jak i OPTIMUS S.A. zmieniało się w czasie i zależało od różnych czynników, m.in. od koniunktury na rynkach międzynarodowych, od inwestycji kapitałowych Spółek, od poziomu produkcji i konsumpcji dóbr produkowanych przez Spółki oraz wahań kursów walut. Czynniki te miały zmienne znaczenia dla ustalania cen akcji.

Przedstawiona analiza, choć nie wyczerpuje w pełni wszystkich przestrzennych aspektów działalności grup kapitałowych w Polsce, dowodzi jednak, że jest to problem badawczy wart szerszego zainteresowania geografów i ekonomistów. Grupy te oraz ich przestrzenna organizacja mają charakter niezwykle dynamiczny i taki też winien być sposób ich analizy. Na razie jednak - ze względu na krótki okres ich funkcjonowania i dużą niestabilność struktur - analiza taka jest trudna do wykonania. Z kolei niewielka liczba grup kapitałowych (a także studiów im poświęconych) utrudnia przeprowadzenie generalizacji, typologii, porównań itp. Przyszłe badania winny określić cechy wspólne oraz specyficzne polskich grup kapitałowych w kontekście międzynarodowym, a także szanse i warunki osiagnnięcia przez nie przewagi konkurencyjnej w globalnej gospodarce.

\section{Literatura}

Domański R., 1982, Teoretyczne podstawy geografii ekonomicznej, Warszawa Haus B., 1993, Ewolucja struktur organizacyjnych przemystu, Warszawa Jagoda H., Haus B., 1995, Holding - organizacja i funkcjonowanie, Warszawa Nogalski B., 2000, Holding: kapitatowo-organizacyjna forma rozwoju MiŚP, Bydgoszcz Sokołowicz W., 1998, Holding: Tworzenie, funkcjonowanie, wzory dokumentów, Warszawa

Sołtysiński S., 1994, Zgrupowania spółek. Zarys problematyki prawnej, Kwartalnik Prawa Gospodarczego, Zeszyt 3

Stryjakiewicz T., 1999, Adaptacja przestrzenne przemystu $w$ Polsce $w$ warunkach transformacji, Poznań

www.kghm.pl

www.optimus.pl 